\title{
Pengaruh Kepuasan Kerja dan Etika Kerja Terhadap Kinerja Melalui Komitmen Organisasi sebagai Variabel Intervening di Dinas Pendidikan Kabupaten Labuhanbatu Utara
}

\author{
Muhammad Arifin'1, Bahril Datuk2 ${ }^{2}$ Sjahril Effendy Pasaribu ${ }^{3}$ \\ 1,2,3 Universitas Muhammadiyah Sumatera Utara, Medan
}

Corresponding Author: \& gopes1983@gmail.com

\section{ABSTRACT}

The purpose of this study was to determine and analyze the effect of job satisfaction and work ethics on performance through organizational commitment as an intervening variable at the Education Office of North Labuhanbatu Regency, either directly or indirectly. The approach used in this study is an associative approach. The population in this study were 43 employees of the North Labuhanbatu Regency Education Office, while the sample in this study was the 43 employees of the North Labuhanbatu Regency Education Office using a saturated sample. Data collection techniques in this study used interview techniques, documentation studies, observation, and questionnaires. The data analysis technique in this study used path analysis, Hypothesis Testing ( $\mathrm{t}$ test and $\mathrm{F}$ test), and the coefficient of determination. Processing data in this study using the software program SPSS version 22. The results of this study prove that directly job satisfaction and work ethics are significant on performance through organizational commitment as an intervening variable and directly on employees of the North Labuhanbatu Regency Education Office.

Keywords

Job Satisfaction, Work Ethics, Organizational Commitment and Performance

\section{PENDAHULUAN}

Dinas Pendidikan Kabupaten Labuhanbatu Utara merupakan salah satu dari 17 dinas daerah dan 33 SKPD (Satuan Kerja Pemerintah Daerah) yang mempunyai tugas untuk melaksanakan urusan pemerintahan daerah berdasarkan asas otonomi dan tugas pembantuan dalam bidang pendidikan. Dalam melaksanakan program kerjanya, Dinas Pendidikan Kabupaten Labuhan Batu Utara berpegang pada visi: Penyelenggaraan layanan pendidikan yang baik, merata, partisipatif dan berkualitas untuk mewujudkan insan yang cerdas, kompetitif dan mandiri lokal berlandaskan pada ketakwaan kepada Tuhan Yang Maha Esa. Setiap organisasi harus mempunyai tujuan yang harus dicapai.

Dalam mencapai tujuan tersebut organisasi tidak lepas dari kontribusi pegawai. Pegawai adalah aset terpenting bagi organisasi. Dengan kepuasan dari pegawai terhadap organisasi. Tak hanya itu, pegawai juga memiliki peran 
penting dalam perkembangan bisnis organisasi. Sebagai pelaku utama dalam mewujudkan tujuan organisasi, pegawai mempunyai pikiran, perasaan dan keinginan yang dapat mempengaruhi sikap-sikapnya terhadap pekerjaannya Sikap-sikap positif hendaknya dibina supaya memberikan efek positif bagi organisasi dan sikap-sikap negatif hendaknya dihindarkan agar tidak memberikan efek negatif bagi organisasi.

Kinerja adalah hasil kerja secara kualitas dan kuantitas yang dicapai oleh seseorang karyawan dalam melaksanakan tugasnya sesuai dengan tanggung jawab yang diberikan kepadanya. Serta menilai bagaimana seseorang telah bekerja dibandingkan dengan target yang telah ditentukan. Kinerja seseorang merupakan kombinasi dari kemampuan, usaha dan kesempatan yang dapat di nilai dari hasil kerja.

Untuk menghasilkan kinerja yang maksimal, organisasi harus mampu menjaga pegawai agar merasa puas terhadap pekerjaan yang dilakukan dan kepuasan dalam menajalankan tugas dengan etika kerja yang baik akan menghasilkan pegawai yang berkomitmen terhadap organisasi.

Kinerja adalah hasil atau tingkat keberhasilan seseorang secara keseluruhan selama periode tertentu didalam melaksanakan tugas dibandingkan dengan berbagai kemungkinan, seperti standar hasil kerja, target atau sasaran,atau kriteria yang telah ditentukan terlebih dahulu dan telah disepakati bersama (Bahri, 2019).

Dari pengertian kinerja diatas dapat disimpulkan bahwa kinerja adalah hasil kerja yang dihasilkan oleh suatu karyawan dalam sebuah perusahaan dan digunakan sebagai tolak ukur dalam mencapai tujuan atau target dalam perusahaan tersebut. Dalam penelitian yang dilakukan pada Dinas Pendidikan Kabupaten Labuhanbatu Utara terdapat permasalahan pada kinerja dimana beberapa pegawai terlambat dalam menyerahkan laporan, dikarena pandemi covid sehingga menuntut mereka bekerja dirumah, berbeda disaat sebelum pandemi, pegawai dengan mudah menyerahkan hasil laporan langsung kepada pihak yang berwenang. Serta terdapat beberapa pegawai didaerah perbatasan mengalami kesulitan untuk menyerahkan laporan terkendala jaringan komunikasi maupun akses jalan sehingga kinerja dari pegawai menurun.

Banyak faktor yang mempengaruhi kinerja, salah satunya adalah Kepuasan Kerja. Menurut Pasaribu (2019) menyatakan bahwa kepuasan kerja adalah ketika seseorang karyawan dapat merasakan pekerjaannya apakah menyenangkan atau tidak menyenangkan untuk dikerjakan. Hasil penelitian terdahulu yang dilakukan (Farisi, 2020) menyatakan bahwa kepuasan kerja berpengaruh positif dan signifikan terhadap kinerja. 
Dinas Pendidikan Kabupaten Labuhabatun Utara memiliki permasalahan pada kepuasan kerja pegawai dimana kurang nya fasilitas sarana maupu prasana dari Dinas Pendidikan Kabupaten Labuhanbatu Utara seperti tidak tersedia Wifi untuk bekerja, demi memudahkan para pegawai Dinas Pendidikan memudahkan dalam menyampaikan hasil laporan melalui daring.

Selain kepuasan kerja, Etika kerja juga mempengaruhi Kinerja, Etika Kerja menjadi permasalahan yang dihadapi oleh Dinas Pendidikan Labuhanbatu Utara. Menurut Pendapat Bhastary (2020) mengemukakan bahwa etika sebagai penyelidikan filsafat berkenaan dengan kewajiban-kewajiban manusia dalam kehidupannya dan juga berkenaan dengan yang baik dan yang buruk. Dalam penelitian ini, peneliti menemukan kendala dimana terdapat beberapa pegawai keluar pada saat jam bekerja daring sedang berlangsung, sehingga materi yang disampaikan mengalami keterlambatan. Serta terdapat beberapa pegawai merokok dikawasan sekolah maupun kantor dinas Pendidikan.

Hasil penelitian terdahulu yang dilakukan Bhastary (2020) menyatakan bahwa Etika kerja berpengaruh positif dan signifikan terhadap kinerja. Lalu Komitmen Organisasi juga turut mempengaruhi Kinerja, Menurut Tanjung (2018) mengemukakan bahwa : “Komiten organisasi adalah suatu keadaan dimana seorang karyawan memihak organisasi tertentu serta tujuan-tujuan dan keinginannya untuk mempertahankan keanggotaan dalam organisasi tersebut". Hal ini didukung penelitian terdahulu Juliandi (2014) yang mengatakan Komitmen Organisasi mempengaruhi Kinerja dengan hasil signifikan dan positif.

Dalam Penelitian ini terdapat kendala pada komitmen organisasi dimana pegawai tidak diikutsertakan dalam pengambilan keputusan oleh pimpinan. Serta terjadinya turnover (pindah kerja) yang akan berdampak dan merugikan organisasi dan dapat menghambat efektivitas dan efisiensin yang selanjutnya akan menurunkan produktivitas organisasi.

Berdasarkan penelitian yang telah dilakukan pada Dinas Pendidikan Kabupaten Labuhanbatu Utara dapat diketahui permasalahan yang ada yaitu, Dinas Pendidikan Kabupaten Labuhanbatu Utara terdapat permasalahan pada kinerja dimana beberapa pegawai terlambat dalam menyerahkan laporan, dikarena pandemi covid sehingga menuntut mereka bekerja dirumah. Serta terdapat beberapa pegawai didaerah perbatasan mengalami kesulitan untuk menyerahkan laporan terkendala jaringan komunikasi maupun akses jalan sehingga kinerja dari pegawai menurun.

Permasalahan lain yang ada yaitu kepuasan kerja pegawai dimana kurangnya fasilitas sarana maupu prasana dari Dinas Pendidikan Kabupaten Labuhanbatu Utara seperti tidak tersedia Wifi untuk bekerja, demi 
memudahkan para pegawai Dinas Pendidikan memudahkan dalam menyampaikan materi laporan pekerjaan melalui daring.

Etika kerja juga menjadi permasalahan pada Dinas Pendidikan Kabupaten Labuhanbatu Utara dimana terdapat beberapa pegawai keluar pada saat jam bekerja daring sedang berlangsung, sehingga laporan/tugas yang disampaikan mengalami keterlambatan. Serta terdapat beberapa pegawai merokok dikawasan lingkungan kerja maupun lingkungan kantor dinas Pendidikan. Serta terjadinya turnover sehingga menurunkan komitmen organisasi.

Berdasarkan uraian diatas penulis membahas masalah pengaruh kepuasan kerja dan etika kerja terhadap kinerja kerja dengan komitmen sebagai variabel intervening dengan tujuan sebagai berikut:

1. Untuk menganalisis Kepuasan Kerja terhadap Komitmen Organisasi di Dinas Pendidikan Kabupaten Labuhanbatu Utara.

2. Untuk menganalisis Etika Kerja terhadap Komitmen Organisasi di Dinas Pendidikan Kabupaten Labuhanbatu Utara.

3. Untuk menganalisis Komitmen Organisasi terhadap Kinerja di Dinas Pendidikan Kabupaten Labuhanbatu Utara.

4. Untuk menganalisis Kepuasan Kerja terhadap Kinerja di Dinas Pendidikan Kabupaten Labuhanbatu Utara.

5. Untuk menganalisis Etika Kerja terhadap Kinerja di Dinas Pendidikan Kabupaten Labuhanbatu Utara.

6. Untuk menganalisis Kepuasan Kerja terhadap Kinerja melalui Komitmen Oranisasi di Dinas Pendidikan Kabupaten Labuhanbatu Utara.

7. Untuk menganalisis Etika Kerja terhadap Kinerja melalui Komitmen Organisasi di Dinas Pendidikan Kabupaten Labuhanbatu Utara.

\section{METODE PENELITIAN}

Pendekatan penelitian ini adalah penelitian survey, karena mengambil sampel dari satu populasi. Penelitian ini menggunakan pendekatan penelitian eksplanatori, yang bertujuan untuk menjelaskan hubungan sebab akibat antara variabel penelitian dan hipotesis pengujian. Penelitian ini termasuk dalam kategori penelitian kausal dengan menggunakan pendekatan kuantitatif.

Tempat penelitian adalah di Dinas Pendidikan Kabupaten Labuhanbatu Utara yang beralamat di Jalan Lintas Sukarame Kelurahan Aek Kanopan Timur, Kecamatan Kualuh Selatan Kabupaten Labuhanbatu Utara. Dilaksanakan mulai dari bulan Mei 2021 sampai dengan September 2021. menggunakan teknik sampling jenuh yaitu teknik penentuan sampel bila semua anggota populasi digunakan sebagai sampel. Sehingga sampel dalam penelitian ini berjumlah 43 orang. 
Untuk memperoleh data yang lengkap dan teliti dalam penelitian, teknik pengumpulan data yang digunakan adalah (1) studi dokumentasi, (2) wawancara (interview) dan (3) daftar pertanyaan (quesioner) dengan skala Likert. Butir jawaban dari daftar pertanyaan kemudian dilakukan uji validitas, reliabilitas, uji asumsi klasik dan analisis jalur menggunakan alat uji statistik SPSS 22.

\section{HASIL DAN PEMBAHASAN}

\section{Hasil}

\section{Uji Validitas}

Adapun hasil uji validitas dalam penelitian ini yang mengunakan SPSS dapat dilihat pada tabel berikut ini:

Tabel 1. Uji Validitas Variabel Kinerja (Y)

\begin{tabular}{|c|c|c|c|}
\hline No & rhitung & ttabel & Keterangan \\
\hline 1 & 0,307 & 0,301 & Valid \\
\hline 2 & 0,471 & 0,301 & Valid \\
\hline 3 & 0,728 & 0,301 & Valid \\
\hline 4 & 0,384 & 0,301 & Valid \\
\hline 5 & 0,496 & 0,301 & Valid \\
\hline 6 & 0,530 & 0,301 & Tidak Valid \\
\hline 7 & 0,262 & 0,301 & Valid \\
\hline 8 & 0,782 & 0,301 & Tidak Valid \\
\hline 9 & 0,275 & 0,301 & Valid \\
\hline 10 & 0,497 & 0,301 & Valid \\
\hline 11 & 0,373 & 0,301 & Valid \\
\hline 12 & 0,370 & 0,301 & \\
\hline
\end{tabular}

Sumber : Data Penelitian Diolah IBM SPSS 22, 2021

Dari tabel diatas hasil output SPSS diketahui sepuluh pertanyaan

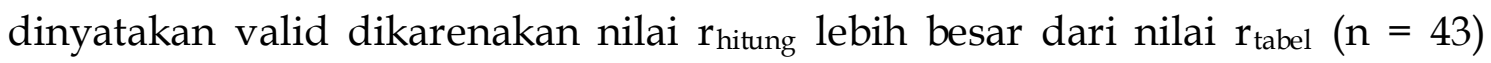
sebesar 0,301. Sedangkan satu pertanyaan dinyatakan tidak valid karena nilai $r_{\text {hitung }}$ lebih kecil dari nilai $r_{\text {tabel }}$.

Tabel 2. Uji Validitas Variabel Kepuasan Kerja $\left(\mathrm{X}_{1}\right)$

\begin{tabular}{|c|c|c|c|}
\hline No & rhitung & $\mathbf{t}_{\text {tabel }}$ & Keterangan \\
\hline 1 & 0,474 & 0,301 & Valid \\
\hline 2 & 0,547 & 0,301 & Valid \\
\hline 3 & 0,544 & 0,301 & Valid \\
\hline 4 & 0,524 & 0,301 & Valid \\
\hline
\end{tabular}




\begin{tabular}{|c|c|c|c|}
\hline 5 & 0,519 & 0,301 & Valid \\
\hline 6 & 0,266 & 0,301 & Tidak Valid \\
\hline 7 & 0,451 & 0,301 & Valid \\
\hline 8 & 0,314 & 0,301 & Valid \\
\hline 9 & 0,132 & 0,301 & Tidak Valid \\
\hline 10 & 0,363 & 0,301 & Valid \\
\hline
\end{tabular}

Sumber : Data Penelitian Diolah IBM SPSS 22, 2021

Dari tabel diatas hasil output SPSS diketahui delapan pertanyaan dinyatakan valid dikarenakan nilai $r_{\text {hitung }}$ lebih besar dari nilai $r_{\text {tabel }}(n=43)$ sebesar 0,301. Sedangkan satu pertanyaan dinyatakan tidak valid Karena nilai

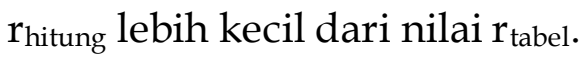

Tabel 3. Uji Validitas Variabel Etika Kerja $\left(\mathrm{X}_{2}\right)$

\begin{tabular}{|c|c|c|c|}
\hline No & rhitung & $\mathbf{t}_{\text {tabel }}$ & Keterangan \\
\hline 1 & 0,654 & 0,301 & Valid \\
\hline 2 & 0,622 & 0,301 & Valid \\
\hline 3 & 0,535 & 0,301 & Valid \\
\hline 4 & 0,412 & 0,301 & Valid \\
\hline 5 & 0,430 & 0,301 & Valid \\
\hline 6 & 0,322 & 0,301 & Valid \\
\hline 7 & 0,170 & 0,301 & Tidak Valid \\
\hline 8 & 0,459 & 0,301 & Valid \\
\hline 9 & 0,462 & 0,301 & Tidak Valid \\
\hline 10 & 0,271 & 0,301 & \\
\hline
\end{tabular}

Sumber : Data Penelitian Diolah IBM SPSS 22, 2021

Dari tabel diatas hasil output SPSS diketahui delapan pertanyaan dinyatakan valid dikarenakan nilai $r_{\text {hitung }}$ lebih besar dari nilai $r_{\text {tabel }}(n=43)$ sebesar 0,301. Sedangkan satu pertanyaan dinyatakan tidak valid Karena nilai rhitung lebih kecil dari nilai $r_{\text {tabel }}$.

Tabel 4. Uji Validitas Variabel Komitmen Organisasi (Z)

\begin{tabular}{|c|c|c|c|}
\hline No & rhitung & ttabel & Keterangan \\
\hline 1 & 0,511 & 0,301 & Valid \\
\hline 2 & 0,609 & 0,301 & Valid \\
\hline 3 & 0,766 & 0,301 & Valid \\
\hline 4 & 0,772 & 0,301 & Valid \\
\hline 5 & 0,633 & 0,301 & Valid \\
\hline 6 & 0,610 & 0,301 & Valid \\
\hline
\end{tabular}

Sumber : Data Penelitian Diolah IBM SPSS 22, 2021 
Dari tabel diatas hasil output SPSS diketahui seluruh pertanyaan

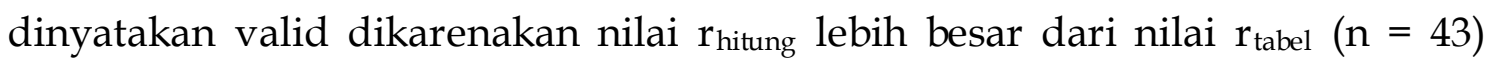
sebesar 0,301. Sedangkan satu pertanyaan dinyatakan tidak valid Karena nilai rhitung lebih kecil dari nilai $r_{\text {tabel. }}$.

\section{Uji Reliabilitas}

Selanjutnya butir instrumen yang valid diatas diuji reliabilitasnya untuk melihat apakah instumen penelitian merupakan instrumen yang handal dan dapat dipercaya. Jika variabel penelitian menggunakan instrumen yang handal dan dapat dipercaya maka hasil penelitian juga dapat memiliki tingkat kepercayaan yang tinggi.

Tabel 5. Hasil Uji Reliabilitas Variabel

\begin{tabular}{|c|c|c|}
\hline Variabel & Nilai Reliabilitas & Status \\
\hline Kinerja $(\mathrm{Y})$ & 0,684 & Reliabel \\
\hline Kepuasan Kerja $\left(\mathrm{X}_{1}\right)$ & 0,686 & Reliabel \\
\hline Etika Kerja $\left(\mathrm{X}_{2}\right)$ & 0,631 & Reliabel \\
\hline Komitmen Organisasi $(\mathrm{Z})$ & 0,720 & Reliabel \\
\hline
\end{tabular}

Sumber : Data Penelitian Diolah SPSS 22, 2021

Instrumen dapat dikatakan reliabel jika nilai koefisien Cronbach Alpha adalah lebih dari 0,6 atau 60\%. Berdasarkan tabel diatas maka dapat disimpulkan bahwa item pernyataan dari masing-masing variabel yang diteliti dinyatakan reliabel karena memiliki nilai Cronbach Alpha dari setiap variabel lebih dari 0,6 atau $60 \%$.

\section{Uji Asumsi Klasik}

Uji Normalitas

Model regresi yang baik dan dapat dipergunakan adalah model regresi yang mempunyai distribusi normal atau mendekati normal. Hasil pengujian normalitas tampak dalam tabel berikut ini:

Tabel 6. Hasil Uji Kolmogorov-Smirnov (KS test)

\begin{tabular}{|l|l|r|}
\hline \multicolumn{2}{|c|}{ One-Sample Kolmogorov-Smirnov Test } \\
\hline \multirow{2}{|c|}{$\mathrm{N}$} & Unstandardized Residual \\
\hline \multirow{2}{*}{ Normal Parameters ${ }^{\mathrm{a}, \mathrm{b}}$} & Mean & 43 \\
\cline { 2 - 3 } & Std. Deviation & .0000000 \\
\hline Most Extreme Differences & Absolute & 2.40739899 \\
\cline { 2 - 3 } & Positive & .095 \\
\cline { 2 - 3 } & Negative & -.095 \\
\hline
\end{tabular}




\begin{tabular}{|l|r|}
\hline Test Statistic & .095 \\
\hline Asymp. Sig. (2-tailed) & $.200 \mathrm{c}, \mathrm{d}$ \\
\hline a. Test distribution is Normal. \\
\hline b. Calculated from data. \\
\hline c. Lilliefors Significance Correction. \\
\hline d. This is a lower bound of the true significance. \\
\hline
\end{tabular}

Sumber : Data Penelitian Diolah SPSS 22, 2021

Dari hasil pengujian tersebut menunjukkan bahwa data telah terdistribusi secara normal. Hal ini ditunjukkan dengan uji Kolmogorov-Smirnov yang menunjukkan hasil yang memiliki tingkat signifikansi sebesar 0.200. karena nilai angka probabilitasnya lebih dari 0,05. Hasil diatas menunjukkan bahwa data berdistribusi normal.

Uji Multikolinearitas

Untuk dapat menentukan apakah terdapat multikolinearitas dalam model regresi pada penelitian ini adalah dengan melihat nilai VIF (Variance Inflation Factor) dan tolerance serta menganalisis matrix korelasi variabel-variabel bebas. Adapun nilai VIF dapat dilihat pada tabel 4.10 dibawah ini :

Tabel 7. Hasil Uji Multikolinearitas

\begin{tabular}{|l|l|r|r|}
\hline \multicolumn{3}{|c|}{ Coefficients $^{\mathbf{a}}$} \\
\cline { 3 - 4 } \multicolumn{3}{|c|}{ Model } & \multicolumn{2}{|c|}{ Collinearity Statistics } \\
\hline \multirow{3}{*}{1} & Tolerance & VIF \\
\cline { 2 - 4 } & Kepuasan Kerja & .708 & \\
\cline { 2 - 4 } & Etika Kerja & .839 & 1.412 \\
\cline { 2 - 4 } & Komitmen Organisasi & .706 & 1.191 \\
\hline \multicolumn{2}{|l|}{ a. Dependent Variable: Kinerja Pegawai }
\end{tabular}

Sumber : Data Penelitian Diolah SPSS 22, 2021

Tabel 4.10 terlihat bahwa dari hasil tersebut menunjukkan bahwa semua nilai VIF dari variabel independent memiliki nilai yang lebih kecil dari 10. Hasil pengujian model regresi tersebut menunjukkan tidak adanya gejala multikolinier dalam model regresi. Hal ini berarti bahwa semua variabel independen tersebut layak digunakan sebagai predictor.

Uji Heteroskedasitas

Pendeteksian ada atau tidaknya heteroskedastisitas dapat dilakukan dengan melihat ada tidaknya pola tertentu pada grafik scatterpolt antara nilai presiksi variabel terikat (ZPRED) dengan nilai residualnya (SRESID). Jika ada pola tertentu yang teratur, maka mengindikasikan telah terjadi 
heteroskedastisitas. Namun jika tidak ada pola yang jelas serta titik-titik menyebar di atas dan di abwah angka 0 pada sumbu Y, maka tidak terjadi heteroskedastisitas. Berikut ini gambar grafik scatterplot yang menunjukkan hasil uji heteroskedastisitas.

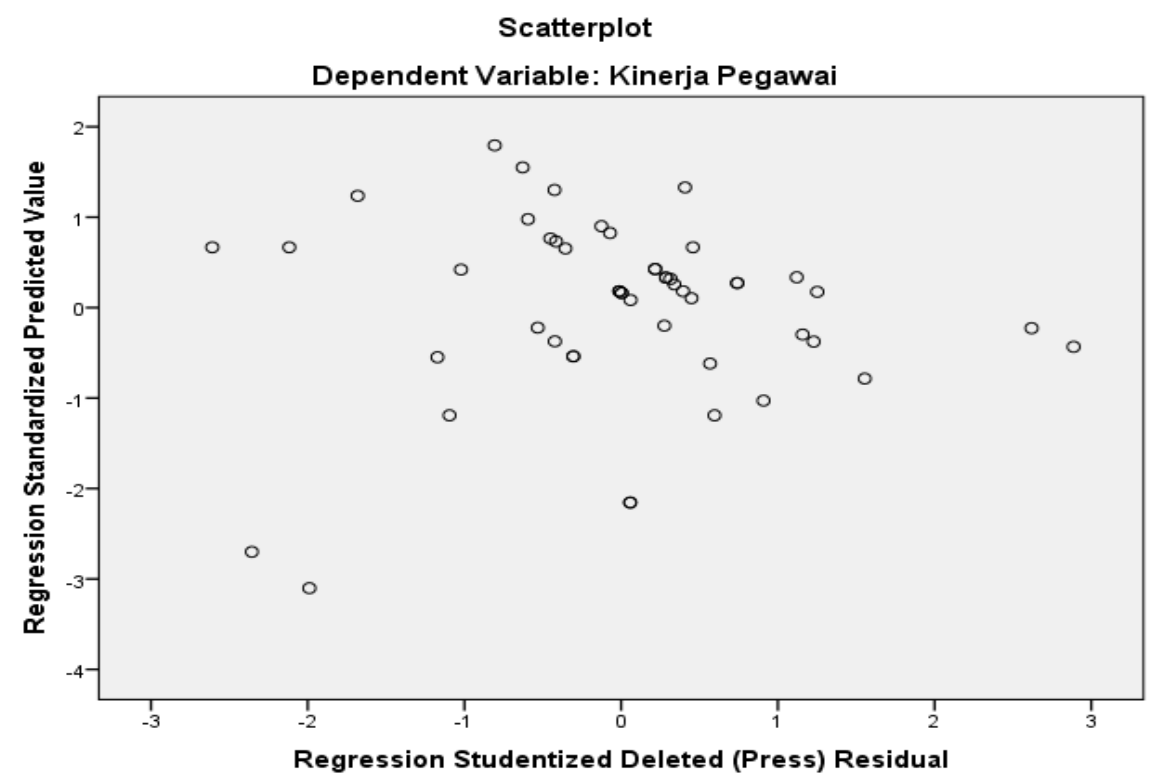

Gambar 1. Hasil Uji Heteroskedastisitas

Gambar diatas memperlihatkan bahwa titik-titik menyebar secara acak serta tesebar di atas maupun di bawah angka 0 pada sumbu Y. Hal ini dapat disimpulkan bahwa tidak terjadi heteroskedastisitas sehingga model regresi layak untuk digunakan.

\section{Analisis Jalur}

Analisis jalur biasa digunakan dalam hal mengetahui pengaruh dari variabel bebas terhadap variabel terikat dengan menggunakan 3 (tiga) persamaan.

\section{Analisis Jalur Persamaan I}

Hasil pengolahan data diperoleh persamaan analisis jalur I (Pengaruh Kepuasan Kerja dan Etika Kerja terhadap Komitmen Organisasi) untuk sebagai berikut:

Tabel 8. Hasil Analisis Jalur Persamaan I

\begin{tabular}{|c|c|c|c|c|c|c|}
\hline \multicolumn{7}{|c|}{ Coefficients $^{a}$} \\
\hline & & \multicolumn{2}{|c|}{$\begin{array}{l}\text { Unstandardized } \\
\text { Coefficients }\end{array}$} & $\begin{array}{c}\text { Standardized } \\
\text { Coefficients }\end{array}$ & \multirow[b]{2}{*}{$\mathrm{t}$} & \multirow[b]{2}{*}{ Sig. } \\
\hline \multicolumn{2}{|c|}{ Model } & B & Std. Error & Beta & & \\
\hline \multirow[t]{2}{*}{1} & (Constant) & 8.353 & 4.697 & & 1.778 & .082 \\
\hline & Kepuasan Kerja (X1) & .432 & .089 & .535 & 4.849 & .000 \\
\hline
\end{tabular}




\begin{tabular}{|l|l|r|r|r|r|r|}
\hline & Etika Kerja (X2) & .480 & .120 & .442 & 4.013 & .000 \\
\hline \multicolumn{7}{|l|}{ a. Dependent Variable: Komitmen Organisasi (Z) } \\
\hline
\end{tabular}

Sumber : Data Penelitian Diolah SPSS 22, 2021

Dari tabel diatas diperoleh model persamaan regresi jalur I yang dapat dituliskan dalam bentuk persamaan regresi jalur I sebagai berikut:

$$
Z=0.535 X_{1}+0,442 X_{2}+\epsilon
$$

\section{Analisis Jalur Persamaan II}

Hasil pengolahan data diperoleh persamaan analisis jalur II (Pengaruh Kepuasan Kerja dan Etika Kerja terhadap Kinerja Pegawai melalui Komitmen Organisasi) untuk sebagai berikut:

Tabel 9. Hasil Analisis Jalur Persamaan II

\begin{tabular}{|c|c|c|c|c|c|c|}
\hline \multicolumn{7}{|c|}{ Coefficients $^{a}$} \\
\hline & & \multicolumn{2}{|c|}{$\begin{array}{l}\text { Unstandardized } \\
\text { Coefficients }\end{array}$} & \multirow{2}{*}{$\begin{array}{c}\begin{array}{c}\text { Standardized } \\
\text { Coefficients }\end{array} \\
\text { Beta }\end{array}$} & \multirow[b]{2}{*}{$\mathrm{t}$} & \multirow[b]{2}{*}{ Sig. } \\
\hline \multicolumn{2}{|c|}{ Model } & $\mathrm{B}$ & Std. Error & & & \\
\hline \multirow[t]{4}{*}{1} & (Constant) & 7.923 & 7.220 & & 1.097 & .278 \\
\hline & Kepuasan Kerja (X1) & .584 & .162 & .515 & 3.606 & .001 \\
\hline & Etika Kerja (X2) & .341 & .206 & .224 & 3.658 & .000 \\
\hline & $\begin{array}{l}\text { Komitmen Organisasi } \\
\text { (Z) }\end{array}$ & .442 & .215 & .401 & 4.662 & .000 \\
\hline
\end{tabular}

Sumber : Data Penelitian Diolah SPSS 22, 2021

Dari tabel diatas diperoleh model persamaan regresi jalur II yang dapat dituliskan dalam bentuk persamaan regresi jalur II sebagai berikut :

$$
Y=0.515 X_{1}+0,224 X_{2}+0.401 Z+\epsilon
$$

\section{Pengujian Hipotesis}

Uji t (Secara Parsial)

Uji t (t-test) ini dimaksudkan untuk mengetahui pengaruh secara parsial (individu) variabel-variabel bebas terhadap variabel terikat atau menguji signifikansi konstanta dan variabel terikat.

1) Hasil Uji t pada persamaan I berdasarkan tabel 8 adalah sebagai berikut :

a) Pengaruh Kepuasan Kerja terhadap Komitmen Organisasi Pegawai. Hasil pengujian regresi I menunjukkan variabel Kepuasan Kerja mempunyai nilai $t_{\text {hitung }} 4,849>t_{\text {tabel }} 1,681$, dengan nilai signifikan 0,000 lebih kecil dari probabilitas 0,05, atau nilai 0,000<0,05, berarti Kepuasan Kerja berpengaruh positif dan signifikan terhadap Komitmen Organisasi pegawai. Maka Hipotesis 1 terbukti. Bahwa Kepuasan Kerja 
berpengaruh positif dan signifikan terhadap Komitmen Organisasi pada Dinas Pendidikan Kabupaten Labuhanbatu Utara.

b) Pengaruh Etika Kerja terhadap Komitmen Organisasi Pegawai. Hasil pengujian regresi 1 menunjukkan variabel Etika Kerja mempunyai nilai $t_{\text {thitung }}^{4,013}>\mathrm{t}_{\text {tabel }} 1,681$, dengan nilai signifikan 0,000 lebih kecil dari probabilitas 0,05, atau nilai 0,000 < 0,05, berarti Etika Kerja berpengaruh positif dan signifikan terhadap Komitmen Organisasi pegawai. Maka Hipotesis 2 terbukti. Bahwa Etika Kerja berpengaruh positif dan signifikan terhadap Komitmen Organisasi pada Dinas Pendidikan Kabupaten Labuhanbatu Utara.

2) Hasil uji t pada persamaan II berdasarkan tabel 9 adalah sebagai berikut:

a) Pengaruh Kepuasan Kerja terhadap Kinerja Pegawai. Hasil pengujian regresi 2 menunjukkan variabel Kepuasan Kerja mempunyai nilai $t_{\text {hitung }}$ $3.606>t_{\text {tabel }}$ 1,681, dengan nilai signifikansi 0,001 lebih kecil dari probabilitas 0,05, atau nilai 0,001 < 0,05, berarti Kepuasan Kerja berpengaruh positif dan signifikan terhadap Kinerja Pegawai. Maka Hipotesis 3 terbukti. Bahwa Kepuasan Kerja berpengaruh positif dan signifikan terhadap Kinerja Pegawai pada Dinas Pendidikan Kabupaten Labuhanbatu Utara.

b) Pengaruh Etika Kerja terhadap Kinerja Pegawai. Hasil pengujian regresi 2 menunjukkan variabel Etika Kerja mempunyai nilai $t_{\text {hitung }} 3.658>t_{\text {tabel }}$ 1,681, dengan nilai signifikansi 0,000 lebih kecil dari probabilitas 0,05, atau nilai 0,000 < 0,05, berarti Etika Kerja berpengaruh positif dan signifikan terhadap Kinerja Pegawai. Maka Hipotesis 4 terbukti. Bahwa Etika Kerja berpengaruh positif dan signifikan terhadap Kinerja Pegawai pada Dinas Pendidikan Kabupaten Labuhanbatu Utara.

c) Pengaruh Komitmen Organisasi terhadap Kinerja Pegawai. Hasil pengujian regresi 2 menunjukkan variabel Kepuasan Kerja mempunyai nilai $t_{\text {hitung }} 3.662>t_{\text {tabel }} 1,681$, dengan nilai signifikansi 0,000 lebih kecil dari probabilitas 0,05, atau nilai 0,000 < 0,05, berarti Komitmen Organisasi berpengaruh positif dan signifikan terhadap Kinerja Pegawai. Maka Hipotesis 5 terbukti. Bahwa Komitmen Organisasi berpengaruh positif dan signifikan terhadap Kinerja Pegawai pada Dinas Pendidikan Kabupaten Labuhanbatu Utara. 
Journal Economy And Currency Study (JECS)

Volume 4, Issue 1, January 2022

Page 49-68

Uji F

1) Uji F pada persamaan I menghasilkan data sebagai berikut:

Tabel 10. Hasil Uji F Pada Persamaan I

\begin{tabular}{|l|l|r|r|r|c|c|}
\hline \multicolumn{7}{|c|}{ ANOVA $^{\mathrm{a}}$} \\
\hline \multicolumn{1}{|l|}{ Model } & Sum of Squares & $\mathrm{df}$ & Mean Square & $\mathrm{F}$ & Sig. \\
\hline \multirow{3}{*}{1} & Regression & 97.737 & 2 & 48.869 & 17.730 & $.000^{\mathrm{b}}$ \\
\cline { 2 - 8 } & Residual & 132.302 & 40 & 2.756 & & \\
\cline { 2 - 8 } & Total & 230.039 & 42 & & & \\
\hline
\end{tabular}

a. Dependent Variable: Komitmen Organisasi $(\mathrm{Z})$

b. Predictors: (Constant), Etika Kerja (X2), Kepuasan Kerja (X1)

Sumber : Data Penelitian Diolah SPSS 22, 2021

Hasil uji F persamaan I menunjukkan $F_{\text {hitung }}$ sebesar $17.730>F_{\text {tabel }}$ sebesar 3,23 dengan nilai signifikansi sebesar 0,000 < 0,05 sehingga variabel Kepuasan Kerja dan Etika Kerja secara simultan berpengaruh positif dan signifikan terhadap Komitmen Organisasi pada Dinas Pendidikan Kabupaten Labuhanbatu Utara.

2) Uji F pada persamaan II menghasilkan data sebagai berikut :

Tabel 11. Hasil Uji F Pada Persamaan II

\begin{tabular}{|c|c|c|c|c|c|c|}
\hline \multicolumn{7}{|c|}{ ANOVA $^{a}$} \\
\hline \multicolumn{2}{|c|}{ Model } & Sum of Squares & $\mathrm{df}$ & Mean Square & $\mathrm{F}$ & Sig. \\
\hline \multirow[t]{3}{*}{1} & Regression & 165.534 & 3 & 55.178 & 9.033 & $.000^{\mathrm{b}}$ \\
\hline & Residual & 287.093 & 39 & 6.108 & & \\
\hline & Total & 452.627 & 42 & & & \\
\hline \multicolumn{7}{|c|}{ a. Dependent Variable: Kinerja (Y) } \\
\hline \multicolumn{7}{|c|}{$\begin{array}{l}\text { b. Predictors: (Constant), Komitmen Organisasi (Z), Etika Kerja (X2), Kepuasan } \\
\text { Kerja (X1) }\end{array}$} \\
\hline
\end{tabular}

Sumber : Data Penelitian Diolah SPSS 22, 2021

Hasil uji F persamaan II menunjukkan $F_{\text {hitung sebesar 9,033 }>F_{\text {tabel }} 2,85}$ dengan nilai signifikansi sebesar 0,000 < 0,05 sehingga variabel Kepuasan Kerja, Etika Kerja dan Komitmen Organisasi secara simultan berpengaruh positif dan signifikan terhadap Kinerja Pegawai pada Dinas Pendidikan Kabupaten Labuhanbatu Utara.

Pengaruh Total

Hasil pengaruh total merupakan penjumlahan antara pengaruh langsung dan pengaruh tidak langsung. Pengaruh total disajikan sebagai berikut: 
Tabel 12. Hasil Pengaruh Langsung dan Pengaruh Tidak Langsung

\begin{tabular}{|c|c|c|c|c|}
\hline No. & Arah Hubungan & $\begin{array}{l}\text { Pengaruh } \\
\text { Langsung }\end{array}$ & $\begin{array}{l}\text { Pengaruh Tidak } \\
\text { Langsung }\end{array}$ & $\begin{array}{c}\text { Total } \\
\text { Pengaruh }\end{array}$ \\
\hline 1. & $\begin{array}{l}\text { Kepuasan Kerja } \longrightarrow \\
\text { Kinerja pegawai }\end{array}$ & 0.515 & & \\
\hline 2. & $\begin{array}{ll}\text { Etika Kerja } & \longrightarrow \\
\text { Kinerja pegawai } & \end{array}$ & 0.224 & & \\
\hline 3. & $\begin{array}{l}\text { Kepuasan Kerja } \longrightarrow \\
\text { Komitmen Organisasi } \rightarrow \\
\text { Kinerja pegawai }\end{array}$ & & $\begin{array}{c}0.535 \times 0.401= \\
0.214\end{array}$ & $\begin{array}{l}0.515+0.214 \\
\quad=0.729\end{array}$ \\
\hline 4. & $\begin{array}{l}\text { Etika Kerja } \longrightarrow \\
\text { Komitmen Organisasi } \rightarrow \\
\text { Kinerja pegawai }\end{array}$ & & $\begin{array}{c}0.442 \times 0.401= \\
0.177\end{array}$ & $\begin{array}{l}0.224+0.177 \\
\quad=0.619\end{array}$ \\
\hline
\end{tabular}

Sumber : Data Penelitian Diolah SPSS 22, 2021

1) Pengaruh Langsung, adalah pengaruh dari satu variabel independen ke variabel dependen tanpa melalui variabel dependen lainnya.

a) Kepuasan Kerja terhadap kinerja pegawai

Berdasarkan tabel 12 diketahui Kepuasan Kerja berpengaruh signifikan terhadap kinerja, dengan nilai koefisiensi sebesar 0.515. Hal ini mengandung arti bahwa semakin baik Kepuasan Kerja maka kinerja pegawai juga akan meningkat.

b) Etika Kerja terhadap kinerja pegawai

Berdasarkan tabel 12 diketahui Etika Kerja berpengaruh signifikan terhadap kinerja, dengan nilai koefisiensi sebesar 0.224. Hal ini mengandung arti bahwa semakin baik Etika Kerja maka kinerja pegawai juga akan meningkat.

2) Pengaruh Tidak Langsung, adalah situasi dimana variabel independen mempengaruhi variabel dependen melalui variabel lain yang disebut variabel intervening (intermediary).

a) Kepuasan Kerja terhadap kinerja pegawai melalui Komitmen Organisasi.

Berdasarkan tabel 12 diketahui pengaruh Kepuasan Kerja terhadap Komitmen Organisasi signifikan sebesar 0.535 dan pengaruh Komitmen Organisasi terhadap kinerja pegawai signifikan sebesar 0.401 sehingga pengaruh tidak langsung sebesar 0.214 .

b) Etika Kerja terhadap kinerja pegawai melalui Komitmen Organisasi.

Berdasarkan tabel 4.23 diketahui pengaruh Etika Kerja terhadap Komitmen Organisasi signifikan sebesar 0.442 dan pengaruh Komitmen Organisasi terhadap kinerja pegawai signifikan sebesar 0.401 sehingga pengaruh tidak langsung sebesar 0.117 . 
3) Kesimpulan Analisis Jalur dan Penggunaan Intervening

Secara lengkap hasil diagram jalur dalam penelitian ini dapat dijelaskan penelitian pada gambar dibawah ini :

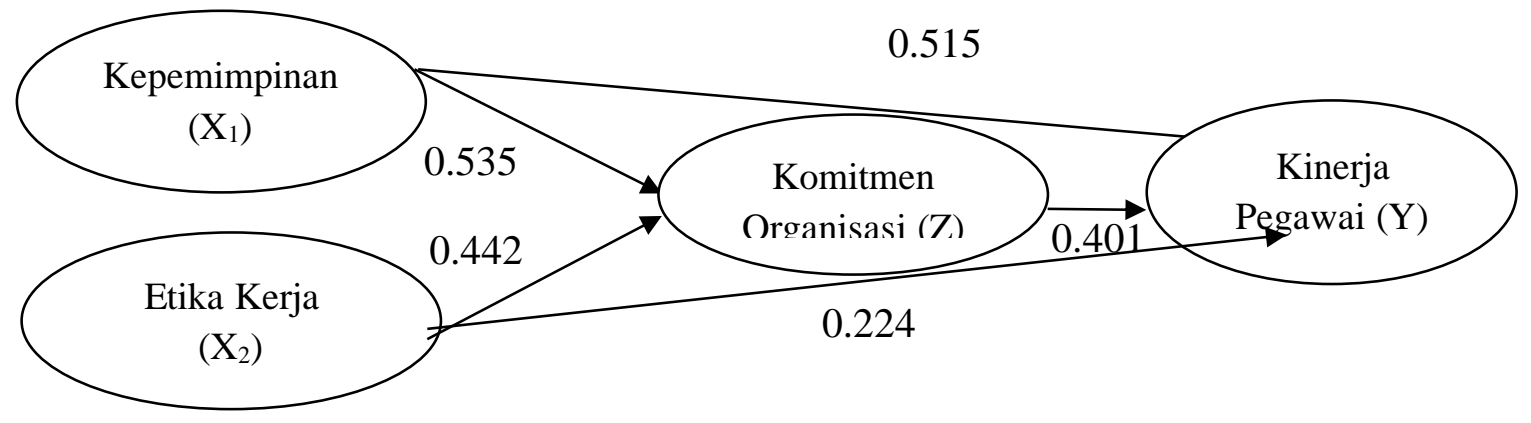

Gambar 2. Diagram Jalur

Berdasarkan hasil analisis pengaruh langsung dan tidak langsung mengindikasikan bahwa :

1) Pengaruh Kepuasan Kerja terhadap kinerja pegawai secara langsung lebih besar yaitu 0.535 dibanding pengaruh tidak langsung melalui Komitmen Organisasi sebesar 0.515, maka Komitmen Organisasi kerja sebagai variabel intervening efektif.

2) Pengaruh Etika Kerja terhadap kinerja pegawai secara langsung lebih besar yaitu 0.442 dibanding pengaruh tidak langsung melalui Komitmen Organisasi sebesar 0.224, maka Komitmen Organisasi sebagai variabel intervening masih kurang efektif.

3) Pengaruh Kepuasan Kerja lebih besar dibandingkan Etika Kerja terhadap kinerja pegawai baik secara langsung maupun tidak langsung melalui Komitmen Organisasi sebagai variabel intervening.

\section{Pembahasan}

\section{Pengaruh Kepuasan Kerja Terhadap Komitmen Organisasi}

Pengaruh Kepuasan Kerja terhadap Komitmen Organisasi di Dinas Pendidikan Kabupaten Labuhanbatu Utara menghasilkan nilai positif dan signifikan. Dari hasil uji statistik diperoleh hasil nilai $t_{\text {hitung }} 4,849>t_{\text {tabel }} 1,681$, dengan nilai signifikan 0,000 lebih kecil dari probabilitas 0,05 , atau nilai 0,000< 0,05, maka Ho ditolak. Sehingga dapat disimpulkan bahwa setiap kenaikan kepuasan kerja akan meningkatkan komitmen organisasi yang ada di dalam diri pegawai Dinas Pendidikan Kabupaten Labuhanbatu Utara. Begitu sebaliknya belum baik kepuasan kerja yang dimiliki seorang pegawai, maka akan menurunkan komitmen organisasi yang dimiliki pegawai.

Penelitian sejalan dengan penelitian terdahulu yang dilakukan oleh oleh Dewi dan Sudibya (2016) dan Mansor et al. (2013) yang menemukan bahwa Kepuasan Kerja mempunyai pengaruh positif terhadap Komitmen Organisasi. 
juga sejalan dengan teori yang di kemukakan oleh Pratama dan Pasaribu (2020) mengatakan bahwa kepuasan kerja merupakan suatu cara pandang seseorang baik yang positif maupun negatif tentang pekerjaannya. Dengan adanya kepuasan kerja pegawai yang terpenuhi maka akan menciptakan Komitmen Organisasi, kepuasan tercipta dengan lingkungan kerja yang nyaman, rekan kerja maupun dari gaya kepemimpinan.

\section{Pengaruh Etika Kerja Terhadap Komitmen Organisasi}

Pengaruh Etika Kerja terhadap Komitmen Organisasi di Dinas Pendidikan Kabupaten Labuhanbatu Utara menghasilkan nilai positif dan signifikan. Dari hasil uji statistik diperoleh hasil nilai thitung 4,013 $>t_{\text {tabel }} 1,681$, dengan nilai signifikan 0,000 lebih kecil dari probabilitas 0,05, atau nilai 0,000<0,05, maka Ho ditolak. Sehingga dapat disimpulkan bahwa setiap kenaikan etika kerja akan meningkatkan komitmen organisasi yang ada di dalam diri pegawai Dinas Pendidikan Kabupaten Labuhanbatu Utara. Begitu sebaliknya belum baik etika kerja yang dimiliki seorang pegawai, maka akan menurunkan komitmen organisasi yang dimiliki pegawai.

Penelitian sejalan dengan penelitian terdahulu yang dilakukan oleh oleh Piola et al. (2019) dan Septiawati (2019) yang menemukan bahwa Etika Kerja berpengaruh signifikan terhadap Komitmen Organisasi, juga sejalan dengan teori yang di kemukakan oleh Bhastary (2020) mengemukakan bahwa etika sebagai penyelidikan filsafat berkenaan dengan kewajiban-kewajiban manusia dalam kehidupannya dan juga berkenaan dengan yang baik dan yang buruk. Etika kerja yang baik akan tercipta apabila pegawai mematuhi dan disiplin terhadap peraturan yang ada. Dengan hal tersebut maka pegawai akan omitmen terhadap organisasi.

\section{Pengaruh Kepuasan Kerja Terhadap Kinerja}

Pengaruh Kepuasan Kerja terhadap Kinerja di Dinas Pendidikan Kabupaten Labuhanbatu Utara menghasilkan nilai positif dan signifikan. Dari hasil uji statistik diperoleh hasil $t_{\text {hitung }} 3.606>t_{\text {tabel }} 1,681$, dengan nilai signifikansi 0,001 lebih kecil dari probabilitas 0,05, maka Ho ditolak. Sehingga dapat disimpulkan bahwa setiap kenaikan kepuasan kerja akan meningkatkan kinerja pegawai yang ada di Dinas Pendidikan Kabupaten Labuhanbatu Utara. Begitu sebaliknya belum baik kepuasan kerja yang dimiliki seorang pegawai, maka akan menurunkan kinerja yang dihasilkan pegawai.

Penelitian sejalan dengan penelitian terdahulu yang dilakukan oleh Dewi dan Sudibya (2016) dan Lodjo (2013) yang menemukan bahwa Kepuasan mempunyai pengaruh positif terhadap Kinerja kerja pegawai. juga sejalan dengan teori yang di kemukakan oleh Jufrizen (2017) mengemukakan bahwa 
kepuasan kerja adalah keadaan emosional yang menyenangkan atau tidak menyenangkan bagi para karyawan memandang pekerjaan mereka.Kepuasan kerja mencerminkan perasaan seseorang terhadap pekerjaannya.

\section{Pengaruh Etika Kerja Terhadap Kinerja}

Pengaruh Etika Kerja terhadap Kinerja di Dinas Pendidikan Kabupaten Labuhanbatu Utara menghasilkan nilai positif dan signifikan. Dari hasil uji statistik diperoleh hasil nilai $t_{\text {hitung }} 3.658>t_{\text {tabel }} 1,681$, dengan nilai signifikansi 0,000 lebih kecil dari probabilitas 0,05, atau nilai 0,000<0,05, maka Ho ditolak. Sehingga dapat disimpulkan bahwa setiap kenaikan etika kerja akan meningkatkan kinerja pegawai yang ada di Dinas Pendidikan Kabupaten Labuhanbatu Utara. Begitu sebaliknya belum baik etika kerja yang dimiliki seorang pegawai, maka akan menurunkan kinerja yang dihasilkan pegawai.

Penelitian sejalan dengan penelitian terdahulu yang dilakukan oleh Narenda (2018) dan Chhabra dan Mohanty (2014) yang menemukan bahwa Etika Kerja berpengaruh positif terhadap kinerja pegawai. juga sejalan dengan teori yang di kemukakan oleh Gultom et al. (2021) etika merupakan penyelidikan filsafat tentang bidang moral, yakni berkenaan dengan kewajiban manusia serta tentang yang baik dan yang buruk. Dengan Etika kerja yang baik dari pegawai, rekan kerja maupun kepemimpinan maka akan terciptanya lingkungan kerja yang baik serta akan meningkatkan kinerja dari pegawai.

\section{Pengaruh Komitmen Organiasi Terhadap Kinerja}

Pengaruh Komitmen Organisasi terhadap Kinerja di Dinas Pendidikan Kabupaten Labuhanbatu Utara menghasilkan nilai positif dan signifikan. Dari hasil uji statistik diperoleh hasil nilai thitung $3.662>t_{\text {tabel }} 1,681$, dengan nilai signifikansi 0,000 lebih kecil dari probabilitas 0,05, atau nilai 0,000<0,05, maka Ho ditolak. Sehingga dapat disimpulkan bahwa setiap kenaikan komitmen organisasi akan meningkatkan kinerja pegawai yang ada di Dinas Pendidikan Kabupaten Labuhanbatu Utara. Begitu sebaliknya belum baik komitmen organisasi yang dimiliki seorang pegawai, maka akan menurunkan kinerja yang dihasilkan pegawai.

Penelitian sejalan dengan penelitian terdahulu yang dilakukan oleh Dewi dan Sudibya (2016) dan Rahman (2014) yang menemukan bahwa Komitmen Organisasi berpengaruh positif terhadap Kinerja, juga sejalan dengan teori yang di kemukakan oleh Luthans (2019) menyatakan bahwa komitmen organisasi adalah : "Sikap yang merefleksikan loyalitas karyawan pada organisasi dan proses berkelanjutan dimana anggota organisasi mengekpresikan perhatiannya terhadap organisasi dan keberhasilan serta kemajuan yang berkelanjutan". Dimana dengan komitmen yang tinggi dari para pegawai maka kinerja 
pegawai akan meningkat, sehingga kualitas dari kinerja yang dihasilkan akan baik.

\section{Pengaruh Kepuasan Kerja Terhadap Kinerja Melalui Komitmen Organisasi}

Hasil penelitian menunjukkan bahwa adanya pengaruh kepuasan kerja terhadap kinerja pegawai Dinas Pendidikan Kabupaten Labuhanbatu Utara melalui komitmen organisasi. Hal ini bisa dilihat dari hasil output SPSS 22.0 dengan analisis regresi masing-masing variabel yang menunjukkan hasil sesuai pada tingkat signifikansinya. Dimana pengaruh Kepuasan Kerja terhadap Komitmen Organisasi signifikan sebesar 0.535 dan pengaruh Komitmen Organisasi terhadap kinerja pegawai signifikan sebesar 0.401 sehingga pengaruh tidak langsung sebesar 0.214 .

Dari hasil diatas menunjukkan adanya pengaruh yang positif signifikan antara kepuasan kerja terhadap kinerja pegawai Dinas Pendidikan Kabupaten Labuhanbatu Utara melalui komitmen organisasi dibawah 0,05, ini menunjukkan $\mathrm{H}_{0}$ ditolak, artinya bahwa kepuasan kerja terhadap kinerja pegawai Dinas Pendidikan Kabupaten Labuhanbatu Utara melalui komitmen organisasi. Dengan demikian semakin baik kepuasan kerja yang ada dalam diri pegawai maka pegawai akan memiliki komitmen organisasi yang kuat dan pada akhirnya akan memberikan kemampuan terbaiknya untuk organisasi sehingga kinerja yang dihasilkannya akan selalu maksimal dalam bekerja.

\section{Pengaruh Etika Kerja Terhadap Kinerja Melalui Komitmen Organisasi}

Hasil penelitian menunjukkan bahwa adanya pengaruh etika kerja terhadap kinerja pegawai Dinas Pendidikan Kabupaten Labuhanbatu Utara melalui komitmen organisasi. Hal ini bisa dilihat dari hasil output SPSS 22.0 dengan analisis regresi masing-masing variabel yang menunjukkan hasil sesuai pada tingkat signifikansinya. Dimana Etika Kerja berpengaruh signifikan terhadap kinerja, dengan nilai koefisiensi sebesar 0.224. Hal ini mengandung arti bahwa semakin baik Etika Kerja maka kinerja pegawai juga akan meningkat.

Dari hasil diatas menunjukkan adanya pengaruh yang positif signifikan antara etika kerja terhadap kinerja pegawai Dinas Pendidikan Kabupaten Labuhanbatu Utara melalui komitmen organisasi dibawah 0,05, ini menunjukkan $\mathrm{H}_{0}$ ditolak, artinya bahwa etika kerja terhadap kinerja pegawai Dinas Pendidikan Kabupaten Labuhanbatu Utara melalui komitmen organisasi. Dengan demikian semakin baik etika kerja pegawai maka pegawai akan memiliki komitmen organisasi yang kuat dan pada akhirnya akan memberikan kemampuan terbaiknya untuk organisasi sehingga kinerja yang dihasilka 


\section{KESIMPULAN}

Berdasarkan hasil penelitian dan pembahasan yang dilakukan oleh penulis mengenai pengaruh Kepuasan Kerja $\left(X_{1}\right)$ dan Etika Kerja $\left(X_{2}\right)$ terhadap Kinerja $(Y)$ di Intervening Komitmen Organisasi $(Z)$ pada Dinas Pendidikan Kabupaten Labuhanbatu Utara, maka dapat ditarik kesimpulan bahwa Kepuasan Kerja memiliki pengaruh positif dan signifikan terhadap Kinerja pada Dinas Pendidikan Kabupaten Labuhanbatu Utara pada Dinas Pendidikan Kabupaten Labuhanbatu Utara. Etika Kerja memiliki pengaruh positif dan signifikan terhadap Kinerja pada Dinas Pendidikan Kabupaten Labuhanbatu Utara pada Dinas Pendidikan Kabupaten Labuhanbatu Utara. Kepuasan Kerja memiliki pengaruh positif dan signifikan terhadap Komitmen Organisasi pada Dinas Pendidikan Kabupaten Labuhanbatu Utara pada Dinas Pendidikan Kabupaten Labuhanbatu Utara. Etika Kerja memiliki pengaruh positif dan signifikan terhadap Komitmen Organisasi pada Dinas Pendidikan Kabupaten Labuhanbatu Utara pada Dinas Pendidikan Kabupaten Labuhanbatu Utara. Komitmen Organisasi $(Z)$ berperan sebagai mediator antara variabel Kepuasan Kerja $\left(\mathrm{X}_{1}\right)$, Etika Kerja $\left(\mathrm{X}_{2}\right)$ dan Kinerja $(\mathrm{Y})$ pada Dinas Pendidikan Kabupaten Labuhanbatu Utara.

\section{REFERENCES}

Adhan, M., Jufrizen, J., Prayogi, M. A., dan Siswadi, Y. (2019). Peran Mediasi Komitmen Organisasi pada Pengaruh Kinerja terhadap Kinerja Dosen Tetap Universitas Swasta di Kota Medan. Jurnal Samudra Ekonomi Dan Bisnis, 11 (1), 1-15.

Agustina, W., dan Bismala, L. (2014). Dampak Pengawasan dan Kinerja Dalam Mempengaruhi Disiplin Kerja Pegawai PT. Perkebunan Nusantara IV (Persero) Medan. Jurnal Riset Akuntansi Dan Bisnis, 14(1), 134-144.

Arda, M. (2017). Pengaruh Kinerja Dan Disiplin Kerja Terhadap Kinerja Pegawai Pada Bank Rakyat Indonesia Cabang Putri Hijau Medan. Jurnal Ilmiah Manajemen Dan Bisnis, 18(1), 45-60.

Arianty, N., Bahagia, R., dan Siswadi, Y. (2015). Manajemen Sumber Daya Manusia.

Astuti, R., dan Lesmana, O. P. A. (2018). Pengaruh Motivasi dan Beban Kerja terhadap Kinerja Perawat pada Rumah Sakit Umum Mitra Medika Medan. Jurnal Ilman, 6(2), 42-50.

Bhastary, M. D. (2020). Pengaruh Komitmen Organisasi dan Stres Kerja terhadap Kinerja Pegawai. Maneggio: Jurnal Ilmiah Magister Manajemen, 3(2), 160170.

Bismala, L., Arianty, N., dan Farida, T. (2015). Perilaku Organisasi.

Dewi, N. M. S., dan Sudibya, I. G. A. (2016). Pengaruh Efikasi Diri Terhadap Organizational Citizenship Behavior Dengan Kinerja Sebagai Variabel Mediasi. E-Jurnal Manajemen Unud, 5(1), 7473-7499. 
Fahmi, M. (2016). Pengantar Manajemen Sumber Daya Manusia Konsep dan Kinerja. Mitra Wacana Medika.

Gultom, D. K., Arif, M., dan Fahmi, M. (2020). Determinasi Kepuasan Pelanggan Terhadap Loyalitas Pelanggan Melalui Kepercayaan. Maneggio: Jurnal Ilmiah Magister Manajemen, 3(2), 171-180.

Handoko, T. H. (2013). Manajemen Personalia dan Sumber Daya Manusia. BPEE.

Hartono, Abdillah, dan Usman. (2019). Konsep dan Aplikasi Struktural Equation Model Berbasis Varian Dalam Penelitian Bisnis. UPP STIM.

Jufrizen. (2021). Komitmen organisasi dan Kinerja Pegawai dengan Komitmen Organisasi sebagai Variabel Intervening.

Jufrizen, J. (2015). Pengaruh Kompensasi Dan Pengembangan Karir Terhadap Komitmen Organisasi Dengan Kinerja Sebagai Variabel Intervening Pada PT. Perkebunan Nusantara III (Persero) Medan. Jurnal Ilmiah Manajemen Dan Bisnis, 15(1), 37-47.

Jufrizen, J. (2017). Efek Mediasi Kinerja Pada Pengaruh Kompensasi Terhadap Kinerja Pegawai. Jurnal iImiah Manajemen Dan Bisnis, 17(01), 34-53.

Jufrizen, J., Gultom, D. K., Sitorus, S. A., Sari, M., dan, dan Nasution, M. I. (2018). The Effect Of Organizational Culture And Islamic Work Ethic On Permanent Lectures' Job Satisfaction, Organizational Commitment And Work Performance At Private Islamic Universities In the City Medan. In Proceeding 1st International Conference of Economic Studies (ICOES), 179-186.

Jufrizen, J., Lumbranraja, P., Salim, S. R. A., dan Gultom, P. (2017). The Effect of Compensation, Organizational Culture and Islamic Work Ethic Towards the Job Satisfaction and the Impact on the Permanent Lecturers. International Business Management, 11 (1) (October), 53-60.

Jufrizen, dan Rahmadhani, K. N. (2020). Pengaruh Budaya Organisasi Terhadap Kinerja Pegawai Dengan Lingkungan Kerja Sebagai Variabel Moderasi. Jurnal Manajemen Dan Bisnis Dewantara Vol., 3(1), 66-79.

Juliandi. (2018). Structural equation model based partial least square SEM-PLS Menggunakan SmartPLS. Jurnal pelatihan SEM-PLS Program Pascasarjana Universitas Batam, 16-17.

Juliandi, A., Irfan, dan Manurung, S. (2015a). Metodologi Penelitian Bisnis.

Juliandi, Irfan, dan Manurung, S. (2015b). Metode Penelitian Bisnis : Konsep dan Aplikasi UMSU Pers.

Kasmir, K. (2016). Manajemen Sumber Daya Manusia Teori dan Praktik. Rajawali Pers.

Kaswan. (2016). Pengembangan Sumber Daya Manusia, Alfabeta.

Khair, H. (2017). Manajemen Kompensasi.

Khair, H., Putri, L. P., dan Bismala, L. (2016). Manajemen Strategi.

Lesmana, M. T., dan Putri, L. P. (2017). Jurnal Riset Sains Manajemen. Analisis Faktor-Faktor Sukses Sistem E-Payment, 1(3), 97-102.

Lodjo, F. S. (2013). Pengaruh Pelatihan, Pemberdayaan dan Efikasi diri Terhadap Kinerja. Jurnal EMBA: Jurnal Riset Ekonomi, Manajemen, Bisnis Dan Akuntansi, 1(3), 747-755.

Luthans, F. (2015). Organizational Behavior. McGraw-Hill Education. 
Mangkunegara, A. A. A. P. (2015). Manajemen Sumber Daya Manusia Perusahaan. PT. Remaja Rosdakarya.

Mangkunegara, A. A. A. P. (2019). Evaluasi Kinerja SDM (Kedua) PT. Refika Aditama.

Mansor, A. A., Darus, M. H., dan Dali. (2013). Mediating Effect of Self-Eficacy on Self Leadership and Teachers' Organizational Citizenship Behavior: A Conceptual Framework. Internasional Journal Of Business and Management Studies, 2(1), 1-11.

Muhammad Djakfar. (2013). Pengaruh Komitmen Organisasi dan Motivasi Terhadap Kinerja Pada PT Berkat Bahari Centralindo.

Piola, M. P. S., Poppy, M., dan Rahmisyari. (2019). Influnce Of Locus Of Control On Organizational Citizenship Behavior Employees In Companies Dringking Water Area. Gorontalo Manajement Research, 2(2), 102-116.

Pratama, P., dan Pasaribu, S. E. (2020). Peran Mediasi Kinerja pada Pengaruh Kepuasan Kerja dan Pengembangan Karir Terhadap Kinerja Pegawai. MANEGGIO: Jurnal Ilmiah Magister Manajemen, 4(September), 259-272.

Prayogi, M. A., Koto, M., dan Arif, M. (2019). Kinerja sebagai Variabel Intervening Pada Pengaruh Work-Life Balance dan Stres Kerja Terhadap Turnover Intention. Jurnal Ilmiah Manajemen Dan Bisnis, 20(1), 39-51.

Rambe, M., Jufrizen, dan Fahmi, M. (2018). Pengaruh Budaya Organisasi dan Komitmen Organisasi Terhadap Kinerja Pegawai. Jesya (Jurnal Ekonomi dan Ekonomi Syariah).

Rastagar, Abbas, A., dan Nina, P. (2013). A Study of The Relationship Between Organizational Justice and Turnover Intentions: Evidence from Iran. International Journal of Research in Organizational Behavior and Human Resource Management, 1(2), 1-10.

Rivai. (2013). Manajemen Sumber Daya Manusia Untuk Perusahaan Dari Teori Untuk Praktik (Ketiga). Rajawali Pers.

Sedarmayanti, S., dan Safer, G. Y. (2016). Pengaruh Motivasi Kerja Terhadap Kinerja Guru Sekolah Dasar Di Gugus Satu Desa Neglawangi Kecamatan Kertasari Kabupaten Bandung. Jurnal Ilmu Administrasi: Media Pengembangan Ilmu Dan Praktek Administrasi, 13(3), 501-524.

Sembiring, M., Jufrizen, J., dan Tanjung, H. (2021). Efek Mediasi Kinerja pada Pengaruh Motivasi Dan Kemampuan Kerja Terhadap Kinerja Pegawai. Maneggio: Junal Ilmiah Magister Manajemen, 4(1), 143-143.

Solimun dan Nurjanah. (2017). Metode Statistika Multivariat Pemodalan Persamaan Struktural. Citra.

Sopiah. (2016). Perilaku Organisasi. Andi.

Sugiyono. (2017). Metode Penelitian Bisnis. Alfabeta. 